\title{
Retrospective evaluation of the factors influencing the mortalities of geriatric patients in a burn intensive care unit
}

\author{
Bir yanık yoğun bakım ünitesinde geriatrik hastaların mortalitelerini etkileyen faktörlerin \\ retrospektif olarak değerlendirilmesi
}

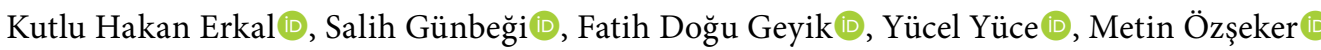 \\ Department of Anesthesiology and Reanimation, \\ University of Health Sciences, Kartal Dr. Lütfi Kırdar Training and Research Hospital, Istanbul, Turkey
}

\begin{abstract}
Objectives: This study aims to evaluate the geriatric patients hospitalized in our burn unit in terms of the changes in demographic distributions and treatment outcomes.

Materials and methods: We evaluated 101 geriatric patients (74 males, 27 females; mean age 66.6 years; range, 65 to 89 years) followed-up between January 2015 and December 2017 at University of Health Sciences Kartal Dr. Lütfi Kırdar Training and Research Hospital Burn Intensive Care Unit (BICU), whose data were correctly available, according to years, age, gender, cause and extent of burn, burn degree, month, season, place of residence, first referred health center, interval from injury to arrival at our burn center, treatment modality, treatment outcomes, and mortality reasons.

Results: The mean total body surface area burned was $21 \%$. The most common etiology was scald burn. The most common etiology of mortalities was flame burn. Mortality rate was $20.3 \%$ with a statistically significant decrease over the years. The most common mortality reason was sepsis. Deaths due to acute renal failure or gastrointestinal hemorrhage also decreased over the years.

Conclusion: Our findings demonstrated that age, burn percentage, or presence of inhalation injury increased mortality in geriatric patients. The Abbreviated Burn Severity Index and Acute Physiology And Chronic Health Evaluation II scores at the start of treatment in the BICU were directly proportional to mortality.

Keywords: Burn, burn etiology, geriatric, mortality, risk factor.
\end{abstract}

$\ddot{o z}$

Amaç: Bu çalışmada yanık ünitemizde yatan geriatrik hastalar demografik dağılımlardaki değişiklikler ve tedavi sonuçları açısından değerlendirildi.

Gereç ve yöntemler: Sağlık Bilimleri Üniversitesi Kartal Dr. Lütfi Kırdar Eğitim ve Araştırma Hastanesi Yanık Yoğun Bakım Ünitesinde Ocak 2015 ve Aralık 2017 tarihleri arasında takip edilen, verileri doğru şekilde bulunabilen 101 geriatrik hasta (74 erkek, 27 kadın; ort. yaş 66.6 yıl; dağılım, $65-89$ yıl) yıllar, yaş, cinsiyet, yanık nedeni ve boyutu, yanık derecesi, ay, mevsim, ikamet yeri, başvurulan ilk sağlık merkezi, yaralanma ile yanık merkezimize geliş arasındaki süre, tedavi yöntemi, tedavi sonuçları ve mortalite nedenlerine göre değerlendirildi.

Bulgular: Yanmış toplam beden yüzeyi alanı ortalama \%21 idi. En yaygın etyoloji haşlanma yanığı idi. Mortalitelerin en yaygın etyolojisi alev yanığı idi. Mortalite oranı yıllar içinde istatistiksel olarak anlamlı bir azalma ile \%20.3 idi. En yaygın mortalite nedeni sepsis idi. Akut böbrek yetmezliği veya gastrointestinal kanamaya bağlı ölümler de yıllar içinde azaldı.

Sonuç: Bulgularımız geriatrik hastalarda yaşın, yanık yüzdesinin veya solunum yaralanması varlığının mortaliteyi artırdığını gösterdi. Yanık Yoğun Bakım Ünitesinde tedavi başlangıcındaki Kısaltılmış Yanık Şiddet İndeksi ve Akut Fizyoloji ve Kronik Sağlık Değerlendirmesi II skorları mortalite ile doğrudan orantılı idi.

Anahtar sözcükler: Yanık, yanık etyolojisi, geriatrik, mortalite, risk faktörü.

Received: November 15, 2018 Accepted: January 30, 2019 Published online: February 18, 2019

Correspondence: Kutlu Hakan Erkal, MD. SBÜ Kartal Dr. Lütfi Kırdar Eğitim ve Araştırma Hastanesi Anesteziyoloji ve Reanimasyon Kliniği, 34890 Kartal, Cevizli، İstanbul, Turkey. Tel: +90 216 - 4583000 e-mail: hakerkal@hotmail.com

Erkal KH, Günbeği S, Geyik FD, Yüce Y, Özşeker M. Retrospective evaluation of the factors influencing the mortalities of geriatric patients in a burn intensive care unit. FNG \& Demiroğlu Bilim Tıp Dergisi 2019;5(1):15-20. 
Burns are defined as a form of injury that occurs in contact with hot or cold materials, burning chemical substances, electrical currents, or radioactive rays due to their temperature. ${ }^{[1]}$ Burns are known to be one of the most frequently observed traumas in developing countries. ${ }^{[2]}$

Increased quality and duration of life brings with it increased populations. According to the World Health Organization, the exact age limit for the definition of elderly is 65 years. ${ }^{[3]}$ Burns that occur in this age group are important traumas that should be considered differently from other age groups. Increasing elderly populations around the world are an indication that more burn patients with older age will be treated in the future.

Burns seen in the elderly are important because of significantly increased morbidity, requirement of hospitalization, and invasive interventions resulting in permanent psychological trauma. Elderly patients have a number of risk factors that increase their mortality and morbidity after burn injury.

Systemic problems such as chronic diseases including adult diabetes, cardiovascular diseases, aging of lung reserves, decrease of body mass index, deterioration of nutritional status, and deterioration of endogenous anabolic hormones increase the risk of mortality after burn injury. ${ }^{[4]}$ Burn, in elderly patients, is characterized by a hypermetabolic response involving massive protein and lipid catabolism, total body protein loss, muscle destruction, peripheral insulin resistance, increased energy expenditure, and increased synthesis of acute phase proteins. ${ }^{[5]}$ Therefore, in this study, we aimed to evaluate the geriatric patients hospitalized in our burn unit in terms of the changes in demographic distributions and treatment outcomes.

\section{MATERIALS AND METHODS}

Our study included 101 geriatric patients (74 males, 27 females; mean age 66.6 years; range, 65 to 89 years) hospitalized in Kartal Dr. Lütfi Kırdar Training and Research Hospital Burn and Wound Treatment Center Burn Intensive Care Unit (ICU) between January 2015 and December 2017. The records of patients were retrospectively reviewed and the demographics, burn percentage (BP), presence of inhalation injury, Acute Physiology and Chronic Health
Evaluation (APACHE) II, and Abbreviated Burn Severity Index (ABSI) burn scores were examined. The study protocol was approved by the Kartal Dr. Lütfi Kırdar Training and Research Hospital Ethics Committee. A written informed consent was obtained from each patient. The study was conducted in accordance with the principles of the Declaration of Helsinki.

\section{Statistical analysis}

The IBM SPSS Statistics version 22.0 program (IBM Corp., Armonk, NY, USA) was used for the statistical analyses. Student's t-test was used for comparison of the descriptive statistical parameters including mean, standard deviation, and minimum and maximum values between the two groups. One-way analysis of variance test was used for multiple comparisons. Statistical significance was set at $\mathrm{p}<0.05$.

\section{RESULTS}

In our study, $88.7 \%$ of the patients were males and $11.3 \%$ were females. The percentage of patients with burns was $30.6 \%$. Of the patients, $28.5 \%$ had additional inhalation damage while $71.5 \%$ had no inhalation damage. The mean ABSI score of the patients was 8.3 (Table 1).

The mean duration of hospitalization (HD) in ICU was 15.5 days (range, 1 to 128 days). The mean mechanical ventilation (MV) duration was 7.4 days (range, 1 to 106 days). The number of operations applied was 17. The APACHE II score ranged between 0 and 35 with a mean of 18.3.

The age groups of our geriatric patients were age $<65,65 \leq$ age $<75$, and $75 \leq$ age. Mortality change was statistically significant depending on age groups $(p<0.01)$. Accordingly, mortality was found to increase as age increased. Mortality rate was lowest at $16.6 \%$ in the group with age $<65$ and highest at $89.4 \%$ in the group with $75 \leq$ age (Table 2).

The mortality rates of male and female patients were $35.8 \%$ and $49.4 \%$, respectively. The mortality difference between male and female patients was not statistically significant (Table 3).

The incidence of burns was evaluated according to the following three groups: $\mathrm{BP}<20,20 \leq \mathrm{BP}<50$, and $50 \leq \mathrm{BP}$; mortality rates significantly increased as the $\mathrm{BP}$ increased (Table 4). 
Table 1. Descriptive statistical values $(n=101)$

\begin{tabular}{|c|c|c|c|}
\hline & $\%$ & Mean \pm SD & Min-Max \\
\hline Age (year) & & $66.6 \pm 13.1$ & $65-89$ \\
\hline $\begin{array}{l}\text { Gender } \\
\text { Male } \\
\text { Female }\end{array}$ & $\begin{array}{l}88.7 \\
11.3\end{array}$ & & \\
\hline Burn percentage & & $30.6 \pm 21.8$ & $0-100$ \\
\hline Abbreviated Burn Severity Index & & $8.3 \pm 3.1$ & $3-15$ \\
\hline Burn Intensive Care Unit hospitalization (day) & & $15.5 \pm 13.2$ & $1-128$ \\
\hline Mechanical ventilation support (day) & & $7.4 \pm 11.3$ & $0-106$ \\
\hline Number of operations & & $1.9 \pm 3.0$ & $0-17$ \\
\hline APACHE II & & $18.3 \pm 8.7$ & $0-35$ \\
\hline Lactate (mmol/L) & & $3.4 \pm 3.0$ & $0.9-9.4$ \\
\hline
\end{tabular}

SD: Standard deviation; APACHE II: Acute Physiology and Chronic Health Evaluation II.

Thirty-one patients had inhalation injury and the mortality rate of these patients was $65.9 \%$. The mortality rate of these patients was significantly higher than patients without inhalation injury (14.3\%). Statistically significant mortality changes were observed due to the presence of inhalation injury (Table 5).

Table 2. Age group and mortality relationship

\begin{tabular}{lcccc}
\hline Age & $\mathrm{n}$ & Mortality (\%) & $\mathrm{SD}$ & $p$ \\
\hline Age $<65$ & 40 & 16.6 & 27.5 & \\
$65 \leq$ age $<75$ & 33 & 25.5 & 45.1 & $<0.01$ \\
$75 \leq$ age & 28 & 89.4 & 42.3 & \\
\hline
\end{tabular}

SD: Standard deviation; $\mathrm{p}<0.05$ : Significant; One-way analysis of variance test was used.

Table 3. Gender and mortality relationship

\begin{tabular}{lcccc}
\hline Gender & $\mathrm{n}$ & Mortality (\%) & $\mathrm{SD}$ & $p$ \\
\hline Male & 74 & 35.8 & 43.8 & 0.35 \\
Female & 27 & 49.4 & 45.7 & \\
\hline
\end{tabular}

SD: Standard deviation; $p<0.05$ : Significant; Student's t-test was used.

Table 4. Burn percentage and mortality relationship

\begin{tabular}{lcccc}
\hline Burn percentage & $\mathrm{n}$ & Mortality (\%) & $\mathrm{SD}$ & $p$ \\
\hline $\mathrm{BP}<20$ & 47 & 9.3 & 23.8 & \\
$20 \leq \mathrm{BP}<50$ & 24 & 19.1 & 36.5 & $<0.01$ \\
$50 \leq \mathrm{BP}$ & 30 & 87.4 & 47.4 & \\
\hline
\end{tabular}

BP: Burn percentage; SD: Standard deviation; $p<0.05$ : Significant; One-way analysis of variance test was used.
The HD was divided into two groups as HD $<7$ days and 7 days $\leq$ HD. The mortality rates of the two groups were $23.6 \%$ and $28.9 \%$, respectively, without a statistically significant difference. Mortality rates were evaluated according to the duration of MV. According to this, MV implementation durations were

Table 5. Inhalation damage and mortality relationship

\begin{tabular}{lcccc}
\hline Inhalation & $\mathrm{n}$ & Mortality (\%) & $\mathrm{SD}$ & $p$ \\
\hline+ & 31 & 65.9 & 43.1 & $<0.01$ \\
- & 70 & 14.3 & 37.2 & \\
\hline
\end{tabular}

SD: Standard deviation; $\mathrm{p}<0.05$ : Significant; Student's t-test was used.

Table 6. Abbreviated Burn Severity Index and mortality relationship

\begin{tabular}{lcccc}
\hline ABSI & $\mathrm{n}$ & Mortality (\%) & $\mathrm{SD}$ & $p$ \\
\hline ABSI $<9$ & 56 & 29.1 & 31.2 & $<0.01$ \\
$9 \leq$ ABSI & 45 & 67.5 & 39.8 & \\
\hline
\end{tabular}

ABSI: Abbreviated Burn Severity Index; SD: Standard deviation; $p<0.05$ : Significant; Student's t-test was used.

Table 7. Acute Physiology and Chronic Health Evaluation II and mortality relationship

\begin{tabular}{lcccc}
\hline Burn percentage & $\mathrm{n}$ & Mortality (\%) & SD & $p$ \\
\hline APACHE II $<10$ & 36 & 25.2 & 22.9 & \\
$10 \leq$ APACHE II $<20$ & 24 & 31.1 & 27.6 & $<0.01$ \\
$20 \leq$ APACHE II & 41 & 67.8 & 27.8 & \\
\hline
\end{tabular}

APACHE II: Acute Physiology And Chronic Health Evaluation II; SD: Standard deviation; $\mathrm{p}<0.05$ : Significant; One-way analysis of variance test was used. 
considered in three groups as non-MV cases, $\mathrm{MV}<7$ days, and 7 days $\leq \mathrm{MV}$. The mortality rate was $11.3 \%$ in cases without $\mathrm{MV}$ and this value was lower compared to the other groups. The mortality rates in the other two groups were close to each other without a statistically significant difference.

The patients' ABSI scores were evaluated as ABSI $<9$ and $9 \leq$ ABSI. Mortality rate was 29.1\% in the group with ABSI $<9$ and $67.5 \%$ in the group with $9 \leq \mathrm{ABSI}$ with a statistically significant difference. As the ABSI score increased, mortality increased (Table 6).

The mortality rate was $25.2 \%$ in group with APACHE II $<10,31.1 \%$ in group with $10 \leq$ APACHE II $<20$, and $67.8 \%$ in group with $20 \leq$ APACHE II. The mortality rate in group with $20 \leq$ APACHE II was significantly higher (Table 7).

\section{DISCUSSION}

Burns cause many medical, psychological, social, and economic problems in all societies. The epidemiological and demographic character of burn injury varies from country to country. In this study, a total of 101 patients over 65 years of age were followed-up in the ICU between January 2015 and December 2017. Of these patients, 54 (26.7\%) died. Our mortality rate was similar to those reported in the literature for adult burn patients, ranging from $4 \%$ to $28.3 \% \cdot{ }^{[6,7]}$

In recent years, many progresses occurred in the treatment of burn injuries; however, the improvement rate of health outcomes in elderly adults with burn injuries is significantly lower than that of young patients. Chronic diseases present in large numbers in elderly patients, while reduced cardiopulmonary reserve and susceptibility to infection and sepsis tend to complicate the preservation of sensitive balances and are considered to be the main causes of high mortality. ${ }^{[8]}$

As with any disease group, age has an important effect on both burn formation as well as treatment outcomes in burn injuries. Elderly are more exposed to burn injuries due to decreased ability to move along with the advancing age, inability to perform fine motor functions, and reduced reflexes. ${ }^{[9]}$
In elderly patients, burn is one of the most frequent causes of death and is ranked at fourth place among deaths due to injuries. ${ }^{[9]}$ Elderly individuals are more vulnerable to burn injuries because of their limited mobility that prevent them from reacting quickly and reaching a safe area when they are in danger. Mabrouk et al. ${ }^{10]}$ reported that $23.7 \%$ of such individuals were unable to act at the scene, and that this increased the severity of injuries in the hospital. In this group of patients, mortality rate compared to burn site is significantly higher than that for younger patients. In young adults, $80 \%$ of the total body surface area (TBSA) burns cause $50 \%$ mortality, while $35 \%$ of the TBSA burns between ages 60 and 70 years cause the same mortality rate. ${ }^{[11]}$ The relationship between age and mortality was examined in geriatric patients admitted to ICU, and mortality was found to increase with increasing age. In the literature, older age was associated with increased mortality rate with reports indicating a mortality rate of $45 \%$ in elderly patients. ${ }^{[12]}$ Our study revealed similar findings.

In terms of the relationship between gender and mortality, one study ${ }^{[13]}$ reported the ratio of males to females in burn patients as 2.6:1 in adults. In that study, $83.2 \%$ of the patients were males while $16.8 \%$ were females. The mortality rates of male and female patients were $20.2 \%$ and $29.4 \%$, respectively, with no significant difference.

In elderly patients, it is necessary to plan burn treatment immediately by starting fluid treatment in those with burns greater than $5-10 \%$ of body surface and any size of inhalation damage. An examination of age and extent of burn reveals that a patient with a burning width of over $50 \%$ is not alive. There is consensus in the literature on increased mortality with increased size of the total burn area. ${ }^{[13]}$

In a study of Kurtoglu et al., ${ }^{[14]}$ BPs were classified as 30-50\%, 50-75\%, and 75\%; while their mortality rates were determined as 66\%, $95 \%$, and $100 \%$. In our study, mortality rate was found to be the lowest with $5.1 \%$ in the group with TBSA $<20$, whereas it increased to $69.2 \%$ in the group with 50\% TBSA according to the literature. These rates are low compared to children and adolescents, and although there are many important developments in burn treatment, it is an important indication that we still fail to treat elderly burn patients. 
In this study, when burn types were examined, thermal burns ranked first with $62.8 \%$, electrical burns ranked second with $28.2 \%$, chemical burns ranked third with $4.9 \%$, and toxic epidermal necrolysis (TEN) burns ranked fourth with 3.9\%. A review of the association of burn types with mortality showed the lowest mortality in patients with electrical burns (5.3\%), while patients with TEN burns had the highest mortality (50.0\%).

The incidence of burn injury and inhalation injury increases with elderly patients due to decreased reaction time. In this age group, reduced seeing, hearing, and reaction time with occasional impairment of reasoning ability are often the main factors in the occurrence of accidents and injuries. We think that the low mortality in electrical burns is due to keeping our patients at follow-up for 24 hours even if they have low grade burns. We also believe that in TEN, even if the burn grade is low, mortality increases with the presence of additional diseases.

An examination of the relationship between inhalation injury and mortality of geriatric patients in the burn ICU demonstrated that mortality was significantly increased in patients with inhalation injury. Of hospitalized burn patients, $30 \%$ have inhalation injury while the presence of an inhalation injury, which is seen in $48-56 \%$ of burn patients with pneumonia, has been reported to cause a two-fold increase in the risk of pneumonia. ${ }^{[15]}$

In our study, $27.7 \%$ of patients had inhalation damage and $55.4 \%$ of these patients died. The mortality rate was found to be significantly increased in cases with inhalation injury. In addition, elderly burn patients have lower threshold that is reached more quickly for MV support during treatment due to reduced lung reserve and earlier fatigue. Heavy-burn geriatric patients may require MV due to many reasons such as inhalation injury, respiratory tract obstruction, pneumonia, acute respiratory distress syndrome, or pulmonary edema.

Studies conducted on the ABSI scores showed that the results were consistent with the scores in full-thickness burns and mortality rates, while low-burn-rate mortality was determined by the duration of hospitalization rather than ABSI. In advanced-age patients with ABSI, higher scores may be noted if age is an important parameter. ${ }^{[16,17]}$ In our study, mortality was significantly increased in patients with high ABSI scores. The mortality rate was $67.5 \%$ in patients with $9 \leq \mathrm{ABSI}$.

The major limitation was the small number of patients included in this study.

In conclusion, the geriatric age group with the highest mortality rate among burn patients require special treatment and follow-up due to the negative effects of burn as well as accompanying diseases and aging on the entire body system. We suggest careful follow-up and a multidisciplinary treatment approach to reduce mortality and morbidity in geriatric burn patients.

\section{Declaration of conflicting interests}

The authors declared no conflicts of interest with respect to the authorship and/or publication of this article.

\section{Funding}

The authors received no financial support for the research and/or authorship of this article.

\section{REFERENCES}

1. DeSanti L. Pathophysiology and current management of burn injury. Adv Skin Wound Care 2005;18:323-32.

2. Fink MP, Abraham E, Vincent JL, Kochanek PM. Textbook of Critical Care. 5th ed. Philadelphia: Elsevier-Saunders; 2005.

3. Samaras N, Chevalley T, Samaras D, Gold G. Older patients in the emergency department: a review. Ann Emerg Med 2010;56:261-9.

4. Abu-Sittah GS, Chahine FM, Janom H. Management of burns in the elderly. Ann Burns Fire Disasters 2016;29:245-9.

5. Williams FN, Herndon DN, Jeschke MG. The Hypermetabolic Response to Burn Injury and Interventions to Modify This Response. Clin Plast Surg 2009;36:583-96.

6. Türegün M, Sengezer M, Selmanpakoglu N, Celiköz $\mathrm{B}$, Nişanci M. The last 10 years in a burn centre in Ankara, Turkey: an analysis of 5264 cases. Burns 1997;23:584-90.

7. Brusselaers N, Juhász I, Erdei I, Monstrey S, Blot $\mathrm{S}$. Evaluation of mortality following severe burns injury in Hungary: external validation of a prediction model developed on Belgian burn data. Burns 2009;35:1009-14.

8. Sadeghi Bazargani H, Arshi S, Ekman R, Mohammadi R. Prevention-oriented epidemiology of burns in Ardabil provincial burn centre, Iran. Burns 2011;37:521-7. 
9. Emami SA, Motevalian SA, Momeni M, Karimi H. The epidemiology of geriatric burns in Iran: A national burn registry-based study. Burns 2016;42:1128-32.

10. Mabrouk A, Maher A, Nasser S. An epidemiologic study of elderly burn patients in Ain Shams University Burn Unit, Cairo, Egypt. Burns 2003;29:687-90.

11. Yanculovich N, Perry ZH, Gurfinkel R, Rosenberg L. Objective estimates of the risk factors for death and length of hospitalization following burn injuries, Soroka University Medical Center, 2001-2002. Isr Med Assoc J 2013;15:152-5.

12. Ryan CM, Schoenfeld DA, Thorpe WP, Sheridan RL, Cassem EH, Tompkins RG. Objective estimates of the probability of death from burn injuries. N Engl J Med 1998;338:362-6.

13. Haberal M, Uçar N, Bilgin N. Epidemiological survey of burns treated in Ankara, Turkey and desirable burnprevention strategies. Burns 1995;21:601-6.

14. Kurtoğlu M, Alimoğlu O, Ertekin C, Güloğlu R, Taviloğlu K. Evaluation of severe burns managed in intensive care unit. [Article in Turkish] Ulus Travma Acil Cerrahi Derg 2003;9:34-6.

15. Tarım MA. Factor affecting mortality in burn patients admitted to intensive care unit. Eastern Journal of Medicine 2013;18:72-5.

16. Greenhalgh DG. Burn resuscitation: the results of the ISBI/ABA survey. Burns 2010;36:176-82.

17. Andel D, Kamolz LP, Niedermayr M, Hoerauf K, Schramm W, Andel $\mathrm{H}$. Which of the abbreviated burn severity index variables are having impact on the hospital length of stay? J Burn Care Res 2007;28:163-6. 